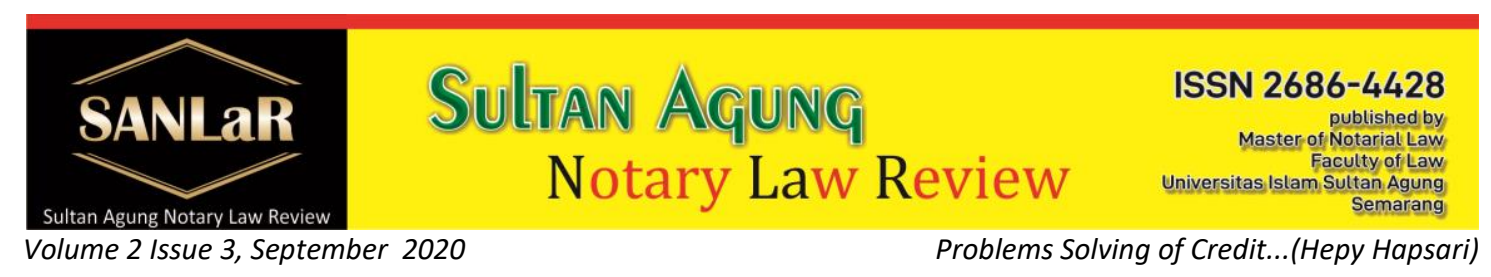

\title{
Problems Solving of Credit with Liability Which Owner Has Died
}

\author{
Hepy Hapsari ${ }^{*}$, Sukarmi $^{* *}$, and Soegianto $\left.{ }^{* * *}\right)$ \\ *) Students of Master of Notary Law, Universitas Islam Sultan Agung (UNISSULA) \\ Semarang, E-mail: hepyhapsari21@gmail.com \\ $\left.{ }^{* *}\right)$ Lecturer of Master of Notary Law, Universitas Islam Sultan Agung (UNISSULA) \\ Semarang \\ ${ }^{* * *}$ Lecturer of Master of Notary Law, Universitas Islam Sultan Agung (UNISSULA) \\ Semarang
}

\begin{abstract}
The purpose of this study was to: 1) To identify and analyze the implementation of the settlement of non-performing credits are collateralized with mortgage collateral while the owner died. 2) To identify and analyze the role of the Notary of the Installation Encumbrance with Certificate Name Properties that have made the process dies down to the Expert Heir based Justice. The data used in this study are primary data, secondary data and data that can support tertiary study, which was then analyzed by descriptive analysis method. Based on the results of data analysis concluded that: 1) the implementation of the settlement of nonperforming credits are collateralized with mortgage collateral while the owner died. 2) the role of the Notary of the Installation Encumbrance with Certificate Name Properties that have made the process dies down to the Expert Heir based Justice.
\end{abstract}

Keywords: Solving; Credit; Liability; Died.

\section{Introduction}

Economic Development as part of national development is an effort for the welfare of a just and prosperous society based on Pancasila and the Constitution of 1945. In order to maintain the sustainability of development, in which the perpetrators include both government and society as individuals and legal entities, it is necessary to fund in large numbers. Economic development and trade that will be followed by the development of demand for credit so that with increasing development, so did the need for the availability of funding, mostly obtained through lending activities.

Civil law governing relationships trading traffic in an effort to meet the needs of human life, one of which is the agreement of Credit Agreement as borrowing money. That the credit agreement has been since time immemorial carried out by many people to make ends meet, which is in the field of Civil Law stipulated in Law Commitments.

As for the so-called Lending and Borrowing Agreement pursuant to Article 1754 Book of Civil Law states: Lending and borrowing is an agreement by which one party gives the other party a certain amount of goods were depleted because of the use on the condition that the latter is will return the same number of sorts and the same circumstances as well. 
Under this agreement, pursuant to Article 1759 Book of Civil Law stipulated that: The borrower shall not hold back on credit before the term of the agreement expires. Meanwhile, according to the Code Article 1763 Civil Code stipulated that: The borrower is obliged to return the same quantity and condition within the specified time.

Also according to the Code Article 1765 Civil Code stipulated that:

The borrower is also obliged to pay interest on borrowing money or goods were depleted due to usage.

Given the importance of credit funds in the development process, it should giver and the recipient of credit protection through a strong guarantee rights institutions and to provide legal certainty for all interested parties to both the providers and recipients of credit ${ }^{1}$.

The bank's involvement as one of the financial institutions have an important role in the economy of Indonesia as stipulated in Act No. 10 of 1998 on the Amendment of Act No. 7 of 1992 on Banking and Act No. 3 of 2004 About Amendment to Act No. 23 of 1999 concerning Bank Indonesia, among others, by giving credits to the borrowers with small bulk and so at this time of banking institutions has been widely recognized by the public as one of the traffic circulation of money, this corresponds to the function of the bank itself where the bank is a form of business entity that collects funds from the public in the form of deposits subsequently distribute those funds to the community in the form of deposits subsequently distribute those funds to the community in order to improve the standard of living.

The lending by banks continues to provide the possibility can not be redemption at maturity. Such credit crunch indirectly also will give a negative impact on the community because bank credit extended to customers it is sourced from public funds. To minimize the losses caused by the bad credits, usually the bank will ask the debtor to provide a guarantee for the credit repayment.

Credit is an important factor in the development of the economy. Definition of credit according to Act No. 10 of 1998 on the Amendment of Act No. 7 of 1992 on Banking are as follows ${ }^{2}$ :

"Credit is the provision of cash or the equivalent, based on agreements between bank lending and other parties who require the borrower to repay the debt after a certain period with interest".

The provision is intended to minimize the risk that will be experienced and also to keep the condition of the bank continues to run in an efficient, fair and reasonable and better able to protect the funds raised by the bank in the community.

The risks in lending can lead to nonpayment of credits when it was the time of redemption. Therefore, in determining whether to grant a credit or not the banker should seek to measure the risk of non-performing credits. This risk is estimated using a process called credit analysts. The goal is to determine a borrower's ability and

\footnotetext{
${ }^{1}$ Chusna, Amalia., \& Hafidz, Jawade. (2019). The Role of the Notary in the Credit Agreement with Mortgage Guarantee (Case Study in the Bank Tabungan Negara (Persero) Tbk). JURNAL AKTA: Vol. 6, No. 4, 719-726. Retrieved from http://jurnal.unissula.ac.id/index.php/akta/article/view/7668

${ }^{2}$ Act No. 7 of 1992 on Banking
} 
sincerity to repay the credit according to the terms contained in the credit agreement. Banks must determine the level of risk that must be endured in each case and the amount of credit to be granted in view of the risk that, in addition to it if it will provide a credit, it is necessary to determine a condition of granting the credit. Some of the factors that affect the ability of a borrower to repay a credit is very difficult to assess, but it must be faced as possible in making financial projections.

According to Edward W Reed Edward K Gill, banks have assessment guidelines or criteria to determine that the debtor is able or unable to repay credits obtained, these criteria are known as The Five C's of Credit Analysis, namely Character, Capacity, Capital, collateral, and condition. ${ }^{3}$ These factors are the things that determine confidence in the capability and capacity of the debtor. The ability of borrowers associated with the legal capacity to borrow. In relation to the concept of the character of credit transactions, not just the willingness to repay the credit but also has a strong desire to fulfill the obligations in accordance with the terms of the agreement. Ownership of assets is equal to capital and credit guarantees. These factors determine the amount of credit granted to the debtor. While the economic conditions affecting the ability of the borrower to repay financial obligations but is beyond the power of the debtor and the creditor.

In order to ensure the interests of the debtor's bank is required to provide a guarantee to the bank, the bank received guarantees that can be land rights, rights to goods, receivables, machinery factories and others. In general guarantee of land rights can provide protection and legal certainty for creditors because it can provide a bank security in terms of its legal and economic value that binds continue from time to time. Warranty is something given to creditors to give rise to the belief that the debtor will fulfill the obligations that can be valued in money arising from an engagement. ${ }^{4}$

Inside, the Indonesian Civil Code known various security institutions such Encumbrance, FEO (Fiduciare Eigendom Overdracht), Cessie, and others. Institutions establish tenure or better known as the granting of mortgage that guarantees repayment of the debtor to afford the charge or certain parcels of land, therefore, the object is agrarian. In Indonesia since 1960 came into force Act No. 5 of 1960 on Basic Regulation of Agrarian later better known as the Basic Agrarian Law (BAL).

In Article 16 paragraph (1) BAL specified kinds of land rights, among others:
a. Right of ownership
b. Cultivation Rights
c. Building rights
d. Right to Use
e. Rental rights
f. Opening Land Rights
g. Picking rights Forest Products
h. Other rights that are not included in the above-mentioned rights will be set by the laws and the rights of temporary as referred to in Article 53.
From a variety of the land rights that may be charged by Encumbrance is:

a. Right of ownership

\footnotetext{
${ }^{3}$ Reed, Edward W. \& Edward K Gill. (1990). Bank Umum. Jakarta: Bumi Aksara. p.185

${ }^{4}$ Hartono, Hadisoeprapto. (1984). Pokok-Pokok Hukum Jaminan. Yogyakarta: Liberty. p. 50
} 


\section{b. Cultivation Rights \\ c. Building rights \\ d. Right to Use}

BAL in Article 51 states that:

Mortgage can be charged to property, right to build, right to cultivate, mentioned in Article 23, 33, 39 is set by statute.

From the article above provisions mean that BAL comes into force since 24 September 1960 which had been promised that it will be set Mortgage as a right that provides coverage for land and objects that are above the ground with the law.

BAL Furthermore, Article 57 states that:

"During law on Mortgage mentioned in Article 51 has not been formed, it will apply the provisions concerning the mortgages in the Book of Civil Law Indonesia and the Verband Credit in Stb. 1908-542, as amended by Stb. 1937-190".

Based on the description of the article means that for a while during legislation is not yet formed, it can be used Verband credit provision. In the colonial era hypotheek conditions used when used as collateral is the right of the west like: Eigendom Rights, Rights and Rights Erfpacht Opstal while credit conditions Verband used when used as collateral is the land of Indigenous Rights Reserved. According to Sutan Remy Sjahdeini, the provision of credit Verband hypotheek and not in accordance with the principles of the national land law and in fact can not accommodate developments in the field of credit and guarantee rights as a result of the progress of economic development. Interpretation differences arose regarding the guarantee on the ground, for example in the case of inclusion of execution.

In the Mortgage Rights Act stipulates that in order to protect the creditor if the debtor defaults is through the execution of mortgage, which in article 6 that:

If the debtor in default, the first security rights holder has the right to sell the object of encumbrance on its own power through the auction and take repayment of its receivable from the sale proceeds.

And Article 20 states that:

a. Mortgage holders first rights to sell the rights object Dependent as aim in Article 6, or

b. Title executorial contained in the Certificate of Mortgage as referred to in Article 14 paragraph (2), the object of Mortgage sold through public auction in accordance with the procedures specified in the legislation for the settlement of receivables holders of Encumbrance with rights precede rather than creditors.

The article gives the holder the right to make the execution of Mortgage object to selling through a public auction without requiring approval from the Mortgage. If the holder of Mortgage is a private bank that the auction must go through the courts to 
first submit a Request Execution Grosse Encumbrance Certificate jo. Granting Mortgage Deed. If the holder of Mortgage is a governmental company or SOE (State Owned Enterprises) and state banks then auction held without trial, but through BPUPLN (Government Agency Affairs State Receivables and Auction) because BPUPLN is a government institution to resolve issues related the accounts of the State.

In Article 20 of the Law Encumbrance (UUHT) above implies that if the debtor's breach, then the object Encumbrance sold through a public auction conducted in accordance with the procedures set out in the regulations.

In connection with the foregoing, the People's Bank of Indonesia Semarang is one of the places to obtain working capital credits for small entrepreneurs. Bank Rakyat Indonesia Semarang is a bank that provides credits with the main target is the small business micro or small enterprises (SMEs) with the proviso that easy. Program lending Bank Rakyat Indonesia Semarang more often give working capital credits and business credits, because of the requirements applicant more easily than others (banking institutions). So much attention from the public.

The extension of credit by Bank Rakyat Indonesia Semarang to the public is done through a credit agreement between recipient of the credit resulting in a legal relationship between the two. Often encountered in the field of credit agreements made by the creditor or in this case the bank, while the debtor is only required to learn and understand it well, as well as the initials and signature approval.

With the meeting held between the lender and the recipient of the credit, there will be a written agreement which can form the basis so that there is rigor and legal certainty between the two. Later agreements were spent in the form of a credit agreement so that the resulting rights and obligations of each party in legal actions.

The agreement in the credit agreement achieved if the credit applicant signed his name on the consent form. This means that the credit applicant has approved the agreement without having consulted beforehand, as the bank credit agreement, the agreement is standard form. In the implementation of the agreement on bank credit in general, can not be separated from numerous problems that often arise in the execution of the credit agreement. Particularly at Bank Rakyat Indonesia Semarang is a state in which the debtor fail to perform its obligations or defaults. Which often happens on the pitch is the debtor either late in paying installments or interest, so that the banks need to conduct preventive supervision, ie supervision performed in the aftermath of bad credits.

Death someone take effect and legal consequences to themselves, their families, communities and the environment. With deaths also occur due to other law automatically, ie the relationship of law concerning the rights of the family (heirs) of the entire wealth legacy. The transfer of rights is still required a legal act any other form of delivery (levering) deed that must be made by an authorized officer. 
As we all know can be transferred besides rights also encumbered encumbrance or used as security for repayment of debt. The credit guarantee should be believed as a guarantee of good and valuable that it would be able to fulfill its functions, having regard to the legal aspects of the guarantee. This is done by the bank so that the bank received confirmation that the credit facilities granted to the public can be used according to needs and can be returned safely and on time.

Mortgage is designed as a security interest is strong, with the hallmark of execution is easy and sure, Mortgage also has properties that can not be divided, it means that the security rights encumber whole object of mortgage and any portion thereof, has paid part of the debt guaranteed, does not mean liberation object security rights in part of the burden of the security rights for the remaining outstanding debts.

\section{Research Methods}

The approach used in this study is juridical empirical method. The first is research data collection juridical empirical approach in this study means that that in analyzing the problems made by combining the ingredients of the law (which is a secondary data) with the primary data collected in the field is about effort Finisher Non Performing Credits secured with the Encumbrance Its Own Security Has Died in Bank Rakyat Indonesia Tbk Semarang. This approach is implemented by conducting direct research of the respondents and informants in the field with the aim to collect objective data, which is referred to as primary data.

\section{Results and Discussion}

3.1. Implementation of the settlement of non-performing credits secured by whereas collateral security rights owner dies

Giving tolerance of the Bank as a creditor to a debtor in default and there is no good faith to complete its obligations to pay the credit to the Bank not without limit in other words when the time limit set by the Bank and the debtor is unable to perform its obligations, the Bank as the creditor can undertake legal measures to terminate the credit agreement even though the deadline for the credit agreement has not ended. In the article 11 of the General Terms of the credit agreement states "By not looking at the provisions of the credit installment and the expiration of the agreement, the Bank reserves the right to terminate or charge the entire debt immediately, and simultaneously without a request to cease and given a warning.

In the end the credit agreement, the action taken by the Bank as creditor is:

a. Confiscation of goods pledged to the Bank in accordance with applicable regulations.

b. Execution and auctions against collateral in accordance with the authorization granted creditor.

c. Settle all remaining debts owned to creditors and to pay the costs incurred and the remainder will be returned to the debtor.

Legal action will be carried out by the Bank while debtors do wan achievements are: 
a. The debtor does not repay the credit in accordance with the amount stipulated in the credit agreement.

b. The debtor to repay the credit but not in accordance with the time specified in the credit agreement.

c. Debtor violates the terms and did not carry out its obligations in accordance with the agreed terms simultaneously.

d. Debtor supply of information that does not correspond to the truth.

When the debtor dies, but its debt or credits have not been repaid. It is the duty of the family to be able to resolve the outstanding debts until paid. The laws that apply in Indonesia, the legacy can be defined as a property that is therein include the assets and debts.

How to help to pay off debts from debtors who have died:

a. Credit insurance is a protection program of the bank granted to anticipate if the customer dies, but credit still running. Usually, credit insurance is cooperating with the insurance so only need to register and pay the amount of any monthly premium.

b. To withdraw funds insurance fund insurance is actually very easy, only need to complete all the required documents. Starting from the letter Description Dies, Certificate of Heirs made by rural / urban, Power of Attorney heirs, a copy of the Customer and heir KK, KK debtor photocopy, photocopy of the marriage certificate, and file a claim from the bank.

c. In filing a claim, to note the term of the claim. Maximum time limit in filing a claim should not be passed within 3-6 months after the client died.

d. Submit Request for Waivers or Debt Eraser

e. System credit insurance usually does not apply to every bank. Another way to do is to ask dried or debt relief. If it feels heavy with inherited debt and can not afford to pay it off, there is no way other than to apply for relief on the bank. The shape of this relief can at least reduce the amount of monthly installments or cut interest credit.

3.2 The role of the Notary of the Installation Encumbrance with Certificate Name Properties

The problems usually will appear in determining who is entitled to be called heirs, determining who is entitled to be called heirs, determination of heirs can be based on the Certificate of inheritance made by the village chief and sub-district, but the heir statement was made without any research at all so unknown certainty, the actual number of heirs heir.

In the case of Process Down Heir to be used as credit guarantees on bank typically issues that arise are objections to one of the heirs to sign the paperwork associated with the process down Heir and the signing of the binding of Credit Guarantee Bank, 
this occurs because of one of these heirs feel not apply for credit in the bank, only brother who is applying for a credit at the bank but because the collateral still yet their parents' names and division of Heir, then automatically all heirs must sign a document to inheritance and Bonding process Down on Bank guarantees.

In this case the Notary must be able to provide a solution or a way out for the parties so that each still protected by law, and obtain justice. Solutions that can be given to the parties in this case the heirs in order to obtain justice and legal certainty is:

a. Providing information about the Law to heir of the importance of keeping the assets together, so that each realize and appreciate the rights and obligations as a family.

b. Installation process is set in Mortgage UUHT, so we must submit to the rule. In the case of installation of Encumbrance with Certificate Name Properties deceased, the heirs must submit to the rules.

If all heirs support each individual's success in advancing its business families personnel, the process of filing with the Bank Credit Mortgage Installation with Certificate rights who have died can be fair without being harmed.

\section{Closing}

Facing problems of the credit has not been repaid by the collateral of land has not been certified, while the debtor has died and left an heir, then there are several ways the settlement made by banks, namely: if the credit is due, then the credit covered by the insurance of credit has expired, then will be billed until paid to the heirs by a family approach by offering relief on credit interest, ask the heirs concerned to make sales under the hand above the object of such guarantee.

\section{References}

Journal:

Chusna, Amalia., \& Hafidz, Jawade. (2019). The Role of the Notary in the Credit Agreement with Mortgage Guarantee (Case Study in the Bank Tabungan Negara (Persero) Tbk). JURNAL AKTA: Vol. 6, No. 4, 719-726. Retrieved from http://jurnal.unissula.ac.id/index.php/akta/article/view/7668

Books:

[1] Reed, Edward W. \& Edward K Gill. (1990). Bank Umum. Jakarta: Bumi Aksara

[2] Hartono, Hadisoeprapto. (1984). Pokok-Pokok Hukum Jaminan. Yogyakarta: Liberty

\section{Regulations:}

[1] Act No. 7 of 1992 on Banking 
[2] Act No. 4 of 1996 on Encumbrance

[3] Act No. 5 of 1960 on Basic Regulation of Agrarian

[4] Government Regulation No. 24 of 1997 on Land Registration 